\title{
小学生・中学生の「いじめ」認識
}

\author{
笠 井 孝 久 $^{1}$
}

\section{COGNITION OF BULLYING (IJIME) BY PRIMARY AND SECONDARY SCHOOL PUPILS}

\author{
Takahisa KASAI
}

\begin{abstract}
This study examined the effects of four situational factors related to bullying (ijime), i.e., the number of attackers, the relationship between the attacker and the attacked, the background of the act, and the type of the act, on children's cognition of an incident as ijime. Four hundred and sixty-eight primary school subjects and 318 secondary school subjects rated the degree to which they agreed the incidents, each of which was made by combining the four factors, as ijime. Three factors effect for primary school subjects' cognition, and all the factors effect for secondary school subjects', as well as some interactions, suggested that pupils' cognition of ijime was affected by a combination of these factors. Although primary school subjects considered the incidents as ijime more often than secondary school subjects, a particular type of act, neglect, was considered to be ijime by secondary school subjects more often than primary school subjects.
\end{abstract}

Key words : bullying (ijime), primary and secondary school pupils, effect of situational factors, developmental difference.

近年，いじめによる自殺等が相次ぎ，多くの機関で その対応に奔走しているが, 根本的な解決には苦慮し ている。いじめは日本だけにみられる現象ではなく, 海外においても関心が高い(Olweus, 1993 ; Sharp \& Smith, 1994)。むしろ, 日本ではいじめ現象が社会現象として 認知されるまでに多くの時間を要したといえよう。こ れには, 子ども集団でのいわゆる「いじめ」が昔から 存在する現象であったこと, 健康的で日常的な攻撃行 動を通して人間関係の摩擦や軋蝶の解決に役立つソー シャルスキルが獲得されるといった認識があったこと などが影響していると考えられる（藤村, 1985 ; 江川, 1986 ; 深谷, 1995), 確かにこのような意味での攻撃行動の体 験は, 子どもの社会化の過程では, むしろ不可欠なこ とともいえる。しかしながら，今日問題視されている

千葉大学教育学部附属教育実践総合センター (Center for Research, Training and Guidance in Educational Practice, Chiba University)
「いじめ」は，そこから登校拒否や自殺，家庭内暴力 などの問題行動が派生しており(稲村, 1985 ; 森田・清永, 1995), その態様や性質の点でも, 影響力の点でも格段 の深刻さをもち，昔ながらのいじめとはまったく性質 の異なったものになったといえるであろう。

このような現状を反映して，いじめに関する実証的 な研究が多く行われている。いじめの実態（深谷・中原， 1986 ; 森田ら, 1995) やいじめにおけるそれぞれの役割 (例 えば,加害者, 被害者, 傍観者)をとる子どもの人格特性や価 值意識などの知見も多く得られている（森田, 1985 ; 井 上・戸田・中松, 1986)。しかしながら, 従来の研究におい ては，何をいじめとするかが研究者によって必ずしも 一致していなかった。濱口・笠井・川端・木村・中澤・ 三浦 (1996) は, 先行研究におけるいじめの定義を概観 し, 継続性, 被害者と加害者の人数比, 加害行為の意 図性, 攻撃行動の程度などの点では, 研究者間で必ず しも一致した見解が見られないことを指摘している 
(高野, 1986, 深谷, 1996 も同様の指摘をしている)。

以前から「いじめはとらえにくい・わかりにくい」 と言われているが(河井, 1986 ; 江川, 1986)，これには， いじめが教師や親の見えないところで起こっている， いじめられた側もその事実を表現できないといった， いじめが顕在化しにくいという意味の他に，ある行為 がいじめなのか, そうでないのかが不明確であるとい う意味も含まれているように思われる。例えば，ある 子どもには「ふざけ」や「圥談」である行為が, 別の 子どもにとっては「いじめ」であったりする。また, 1 人の子どもの中でも, 仲良しの友だちの行為であれ ば何でもないことが, 乱暴でいじわるな友人の行為だ といじめととらえられることもあり, いじめか否かの 判断には, 行為の背景や文脈が大きく影響すると推測 される。

このように“何をいじめとするか”には, 非常に主観 的な要素が含まれ，このことが教育現場での具体的か つ有効な指導を困難にさせている原因の 1 つと考えら れる。とりわけ「いじめ」と「ふざけ」,「圥談」,「ケ ンカ」といった何らかの攻撃的要素の含まれる概念の 判別は, 被害者と加害者の見解の違いなども加わって, より一層, 難しいものになっていると言えるだろう。

ところで, 現実に生起しているいじめ現象の理解や 解決策を模索するためには, 坂本 (1995) や鈴木 (1995) が，いじめられている側の「いじめられている」とい う認識や主観を強調しているように, いじめの当事者 である児童・生徒の視点から,より具体的な行動とし てのいじめをとらえることが必要である。いじめの特 徵の 1 つとして, 加害者のいじめている意識の欠如(江 川, 1986 ; 深谷, 1996）や正当化・正義のいじめ（江川, 1986 ; 河井, 1985, 1986) などが指摘されているが，これらは加 害者と被害者とのいじめの認識の違いに端を発してい るともいえる。「圥談」でやった行為も「いじめ」にな る可能性があるといった認識を育てるためには，まず “何がいじめとなるのか”という具体的な共通認識を持 つ必要がある。その上に立って初めて, 自分の行動を 抑制したり，他者の行動を制止することが可能になる のではないだろうか。

そこで本研究では,この共通認識の基盤となる, 小・ 中学生がどのような行為をいじめととらえているか, 特にいじめの判断がされる際に，「いじめ」現象を構成 する主観的・状況的要因がどのように影響しているか を明らかにすることを目的とする。このような認知的 アプローチから導き出される結果は, いじめを防止す るための指導場面において, 自分や他者の行為がいじ
めに該当する可能性がどの程度あるのかといった問題 を考える際の参考資料として提供できるであろう。こ れらの資料を利用することにより, 自分に悪意はなく とも，相手の立場からすればいじめになるかもしれな いといった認識が形成されることが期待される。

本研究では, 「加害者の人数」,「加害者と被害者の関 係」,「行為の背景」,「行為の形態」という 4 要因を操 作した具体的場面を構成し, それらがどの程度, いじ めと認識されるかを, いじめが問題となる小学校高学 年と中学生を対象に調査することとした。また, 発達 的に考えると, 小学校中学年以降, いわゆるギャング・ エイジに突入し思春期へと移行する間に, 自己認識や 友人関係の質にかなりの変化が生じる。これらの変化 に伴い, 他者からなされた行為に対する認識やその認 識の形成に影響を与える要因などに質的な変化が生じ ることも予想される。そこで, 小学生と中学生のいじ め認識の差異やそれに影響を及ほす要因の違いについ ても検討する。

\section{方法}

\section{1. 調查対象}

小学生：千葉県内の公立小学校, 6 校 12 学級の 5 年 生 468 名(うち男子 268 名,女子 200 名), 中学生：千葉県内の 公立中学校, 3 校 9 学級の 2 年生 318 名(うち男子 160 名, 女子 158 名)。

\section{2. 調查内容}

\section{(1)項目の選定}

いじめの判断をする際に影響を及ぼすと考えられる 要因として, 先行研究（高野, 1986 ; 濱口ら, 1996）を参考 にして以下の 4 要因を設定した。

a ．加害者と被害者との関係 (以下, 関係と記す)

松本 (1985) が，いじめを「集団的な状況における人 間関係のコンフリクトの 1 つの形態」ととらえている ように，いじめには人間関係的な要素が強く影響を与 えていると考えられる。また，仲のよい友人からされ た行為と，いじわるな友人からされた行為とでは，そ の行為のとらえ方が異なることは容易に推測される。 そこで, 加害者と被害者との関係として以下の 3 水準 を設定した。

仲よし：いつも一緒に遊んだり，話したりしている 仲のよい友人。

交渉なし：ふだん一緒に遊んだりしないし，あまり 話しもしない友人。

仲悪い：よくいじわるをしてきて，ケンカしたりし ている友人。 
b . 加害者の人数 (以下, 人数と記す)

多くの研究者が, 今日のいじめの特徴として「いじ めの集団化」, すなわち大勢で 1 人の対象を攻撃すると いうことをあげている（江川, 1986 ; 森田ら, 1995)。児童・ 生徒がこのような 1 対多数という構図をいじめととら えているならば，1 対 1 あるいは集団対集団という形 態は, 一方的という色合いが減少し，その行為は「ケ ンカ」や「対立」としてとらえられる可能性がある。 そこで，加害者の人数として，1人の被害者に対して 単数と複数の 2 水準を設定した。

c. 行為の背景 (以下, 背景と記す)

いじめた理由を調査した先行研究からは，「(被害者 が)掃除をさぼっから」というような被害者の行為に 対する制裁や，「相手を明るくするため」といった，あ る種の正義感からの行為も出現している（河井, 1985 ; 江 川, 1986)。被害者にはいじめとしてとらえられる行為 も, 加害者の意図や行為の背景によっては, いじめと 見なしてよいのか判断が難しい場合もあり，これらの 要因もいじめの認識に大きな影響を与えていると推察 される。そこで, 行為の背景として, 以下の 3 水準を 設定した。

面白い：(加害者が）面白がって。

しかえし：(被害者が）悪口をいったので。

ぼんやり：(被害者が) ぼんやりしていたので。

d. 行為の形態 (以下, 形態と記す)

軽微な行為なら「ふざけ」や「遊び」として斉ませ られるが, 暴力的な行為などは明らかにいじめと判断 されるように，加えられた攻撃行動の形態とそれに対 する認識は，ある程度関連していると考えられる。ま た, 先行研究から (深谷・中原, 1986 ; 古市・余公・前田, 1989) 学年や性別によって経験するいじめ行為の形態が異な ることも指摘されている。このことから, 学年や性別 などの被験者の属性によって, どのような形態の行為 をいじめととらえるかが異なることも予想される。そ こで, 先行研究 (笠井, 1996) を参考に, いじめと見なさ れる行為の被害感（されて嫌だと思う程度）が同程度にな るように以下の 4 水準を設定した。

ことば：からだの欠点を言う。

暴力：押したり，足を引っかけたりする。

無視：1日中, 話しかけない。

嫌がらせ：筆箱やノートを隠す。

\section{(2)質問紙の構成}

関係 $(3$ 種 $) \times$ 人数 ( 2 種) をクロスさせた 6 セットの 質問紙を作成した。各セットには背景 ( 3 種) $\times$ 形態 $(4$ 種）の12項目が含まれる。
被験者の負担を考慮し，それぞれの児童・生徒が 6 セット中 4 セットの質問紙を実施するように冊子を構 成した。その際, 組み合わせと提示順序の効果も考慮 し，48通りの提示パターンを作成した(具体的な質問紙の) 例は FGURE 1, APPENDIX I 参照)。

いつもあなたといっしょに話したり遊んだりしている，なん人 かの仲よしの同級生が，つぎの 1 ～12のようなことをしたら, あ なたはそれを「いじめ」だと思いますか。

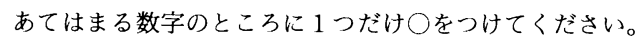

1）おもしろがって,「チビ」などとあなたのからだの欠点をいっ た

\begin{tabular}{|c|c|c|c|}
\hline \multicolumn{4}{|c|}{ 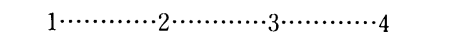 } \\
\hline とても & かなり & 少し & ぜんぜん \\
\hline そう思う & そう思う & そう思う & そう思わない \\
\hline
\end{tabular}

FIGURE 1 質問紙の例

(「仲よし $\times$ 複数」条件,「背景」：面白い,「形態」：ことば）

\section{3. 手続き}

平成 7 年 12 月。調査は授業時間の一部を割いて実施 された。担任教諭に実施方法を説明し，集団一斉実施 を依頼した。所要時間は約30分。

それぞれのセットに FIGURE 1 のような教示を与え， 提示された行為がどれくらいいじめと思われるかを尋 ねた。「とてもそう思う」，「かなりそう思う」，「少しそ う思う」，「ぜんぜんそう思わない」の 4 段階で回答を 求めた。

\section{結果と考察}

\section{1. 結果の処理}

それぞれの項目の回答について，いじめに該当する と思うほど得点が高くなるように, 上記の順に 4 〜 1 点を与えた。

\section{2. 小学生のいじめ認識}

小学生の項目別, および各要因の水準別平均值と標 準偏差を TABLE 1 に示した。質問紙の提示パターンに よる効果を考慮し，一元配置分散分析をしたところ， 有意な差は見られなかった。よって，提示パターンに よる効果は考慮せずに分析を進めることとした。

本研究では, 被験者への負担の軽減などの観点から, 計画的なデー夕収集ができなかったので，通常の実験 計画を適用することが難しい。よって，比較する平均 値の差が，それぞれの標準誤差の 2 倍以上であれば, $5 \%$ 水準で有意差を認めることができると考え, ここ では，平均值の差がそれぞれの標準詔差の 3 倍を越え 
TABLE 1 小学生の項目別要因別平均値

\begin{tabular}{|c|c|c|c|c|c|c|c|c|c|c|c|c|c|c|c|}
\hline & & \multicolumn{4}{|c|}{ (加害者が)面白い } & \multicolumn{4}{|c|}{ （被害者の行為に対する）しかえし } & \multicolumn{4}{|c|}{ （被害者が）ほんやり } & \multirow{2}{*}{$\begin{array}{l}\text { 関係別 } \\
\text { 平均 }\end{array}$} & \multirow{2}{*}{$\begin{array}{l}\text { 人数別 } \\
\text { 平均 }\end{array}$} \\
\hline & & ことば & 暴力 & 無視 & 嫌がらせ & ことば & 暴力 & 無視 & 嫌がらせ & ことば & 暴力 & 無視 & 嫌がらせ & & \\
\hline \multirow{4}{*}{ 仲よし } & \multirow{2}{*}{ 単数 } & $\underline{2.04}$ & $\underline{2.26}$ & 2.39 & $\underline{2.68}$ & 1.65 & $\underline{1.92}$ & 1.79 & $\underline{2.24}$ & 2.50 & 2.27 & 2.19 & $\underline{2.64}$ & & \\
\hline & & $(.98)$ & $(1.00)$ & $(1.04)$ & $(1.07)$ & $(.76)$ & $(.84)$ & $(.87)$ & $(.98)$ & $(1.02)$ & $(1.01)$ & $(1.09)$ & $(1.06$ & 仲よし & 単数 \\
\hline & \multirow{2}{*}{ 複数 } & $\underline{2.17}$ & $\underline{2.37}$ & 2.42 & $\underline{2.78}$ & 1.65 & $\underline{1.98}$ & 1.83 & 2.18 & $\underline{2.52}$ & $\underline{2.30}$ & 2.14 & $\underline{2.73}$ & $\underline{2.22}$ & $\underline{2.33}$ \\
\hline & & $(.96)$ & $(.95)$ & $(1.02)$ & $(1.01)$ & $(.74)$ & $(.85)$ & $(.86)$ & $(.86)$ & $(1.00)$ & ( .99) & $(1.04)$ & $(1.00)$ & $(.68)$ & (.61) \\
\hline \multirow{4}{*}{ 交渉なし } & \multirow{2}{*}{ 単数 } & 2.38 & 2.73 & 1.94 & 2.98 & 1.74 & 2.05 & 1.68 & 2.31 & $\underline{2.67}$ & 2.47 & 1.91 & 2.92 & \multirow{2}{*}{ 交渉なし } & \multirow[b]{2}{*}{ 複数 } \\
\hline & & $(.97)$ & $(.94)$ & $(1.00)$ & $(.97)$ & $(.82)$ & $(.89)$ & $(.83)$ & $(.83)$ & ( . .99) & $(1.01)$ & ( . .99) & $(1.00)$ & & \\
\hline & \multirow{2}{*}{ 複数 } & 2.50 & $\underline{2.82}$ & 2.11 & $\underline{3.11}$ & 1.78 & 2.07 & 1.70 & 2.39 & $\underline{2.76}$ & $\underline{2.56}$ & 1.92 & $\underline{2.97}$ & \multirow{2}{*}{$\frac{2.33}{(.61)}$} & 2.37 \\
\hline & & $(.90)$ & (.95) & $(1.03)$ & $(.89)$ & $(.77)$ & $(.82)$ & $(.85)$ & $(.95)$ & $(.94)$ & $(.94)$ & $(1.00)$ & $(.96)$ & & ( . .63) \\
\hline \multirow{5}{*}{ 仲覀い } & \multirow{2}{*}{ 単数 } & 2.52 & 2.80 & 2.35 & $\underline{3.13}$ & 1.88 & 2.14 & 1.77 & $\underline{2.44}$ & 2.77 & $\underline{2.62}$ & 2.01 & 3.00 & \multirow{3}{*}{ 仲悪い } & \\
\hline & & $(.98)$ & ( . .95) & $(1.06)$ & $(.94)$ & $(.86)$ & $(.90)$ & $(.82)$ & $(.94)$ & ( . .99) & $(1.00)$ & $(1.00)$ & ( . .95) & & \\
\hline & & & & & & & & & & & & & & & \\
\hline & \multirow{2}{*}{ 複数 } & 2.74 & 2.89 & 2.42 & $\underline{3.18}$ & 1.94 & 2.16 & 1.85 & 2.46 & $\underline{2.87}$ & $\underline{2.67}$ & 2.12 & 3.03 & \multirow{2}{*}{$\frac{2.56}{(.66)}$} & \\
\hline & & $(.94)$ & $(.95)$ & $(1.10)$ & $(.92)$ & $(.86)$ & $(.96)$ & $(.85)$ & $(.98)$ & $(.98)$ & $(1.00)$ & $(1.06)$ & $(.96)$ & & \\
\hline
\end{tabular}

\begin{tabular}{|c|c|c|c|c|c|c|c|c|}
\hline & 面白い & しかえし & ほんやり & & ことば & 暴力 & 無視 & 嫌がらせ \\
\hline \multirow{2}{*}{ 背景別平均 } & $\underline{2.56}$ & 1.97 & $\underline{2.51}$ & \multirow{2}{*}{ 形態別平均 } & $\underline{2.22}$ & $\underline{2.37}$ & 2.05 & 2.71 \\
\hline & $(.64)$ & $(.58)$ & $(.70)$ & & $(.59)$ & (.63) & $(.67)$ & $(.72)$ \\
\hline
\end{tabular}

・( )内は標準偏差

・—_.... は, $\mathrm{t}$ 検定による小中比較により，5\%水準で有意差が見られたもの（_—小>中， ....小小中）

ていれば有意な差があるとみなして論じていくことと する。

要因別水準別に平均値を算出したところ, すべての

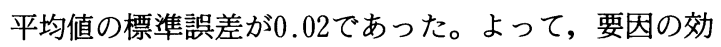
果は平均値の差が 0.06 以上の場合に有意な差があるも のとみなす。効果の認められた要因は, 関係, 背景, 形態であった。関係では,「仲悪い>交渉なし>仲よし」 という結果が得られた(>は, 有意差が認められたもの。以下 同様江表記する)。背景では, 「面白い n.s.浑んやり>しか えし」という結果であった。しかえしという状況は明 らかにいじめと認識されにくいことは, 被害者に何ら かの落ち度があり, それをこらしめる形で行われる行 為は, 許容される度合いが高いという井上ら (1986) の 調査結果と一致している。

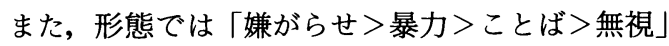
という順序でいじめと認識されることが示された。

要因の組み合わせによる効果（交互作用）については, それぞれ組み合わせごとに平均値を算出し，上と同様
の方法（比較する平均値の標準誤差の 3 倍を基準とする）を用 いて, 平均値の差異の平行性からのズレについて検討 することとした。その結果, 人数 $\times$ 関係, 関係 $\times$ 背景, 関係 $\times$ 背景, 背景 $\times$ 形態において組み合わせの効果が 見られた。

人数 $\times$ 関係 (有意差の基準: 0.12 ) では, 加害者が単数 の場合, 仲よしと交渉なしの間に差はないが(仲よし (2.21)n.s.交涉なし(2.32)), 複数では有意差が認められた(仲 よし(2.26)<交涉なし(2.39))。

関係×背景 (基準: 0.12) おいては，しかえしが他の背 景よりいじめと認識されにくいのは, 関係のすべての 水準に共通しているが, 仲の悪い友人の行為では, 面 白いとほんやりの間にも有意な差がみられた（仲よし： 面白い(2.34)n.s.注んやり(2.42)>しかえし(1.90). 以下同順で, 交 渉なし：2.57n.s.2.52>2.14, 仲悪い：2.75>2.63>2.08)。また, 面白いという背景においてのみ, 交涉なしの友人と仲 の悪い友人との間に有意差が見られた。

関係 $\times$ 形態（基準: 0.12）では（FIGURE 2-a）こととばと 
いう形態では, 仲の悪い, 交涉のなし, 仲よしの順で いじめと認識されやすいが（ことば：仲悪い(2.45)>交渉な し(2.30)>仲ょし(2.09))，暴力では仲悪いと交渉なしの間 に，嫌がらせでは仲よしと交涉なしの間に差がなかっ た（上と同順で, 暴力: 2.55 n.s.2.45>2.18, 嫌がらせ : $2.87>2.56$ n.s.2.54)。無視では, 仲悪いと仲良しの間に差がなかっ た(仲悪い(2.20)n.s.仲よし(2.13)>交涉なし(2.00))。普段交涉の ない友人から無視されてもそれほどのことではないが, 仲よしの友人から無視されると, 普段仲良くしている だけに仲の悪い友人からされるのと同等のいじわるな 行為ととらえられるのであろう。また，仲よしの行為 では, ことば, 無視, 暴力という形態の差はなかった。

背景 $\times$ 形態 (基準: 0.09) では (FIGURE 2-b), 暴力, 無 視という形態においては，いじめの認識されやすさが 「面白い>ほんやり」という順であるが（暴力：面白い (2.65)>ほんやり(2.48)n.s.しかえし(2.41)。以下同順で，無視： $2.27>2.05>1.77)$, 嫌がらせは, 面白いとほんやりという 背景の差はなく（面白い(2.98)n.s.ぽやり(2.89)>しかえし

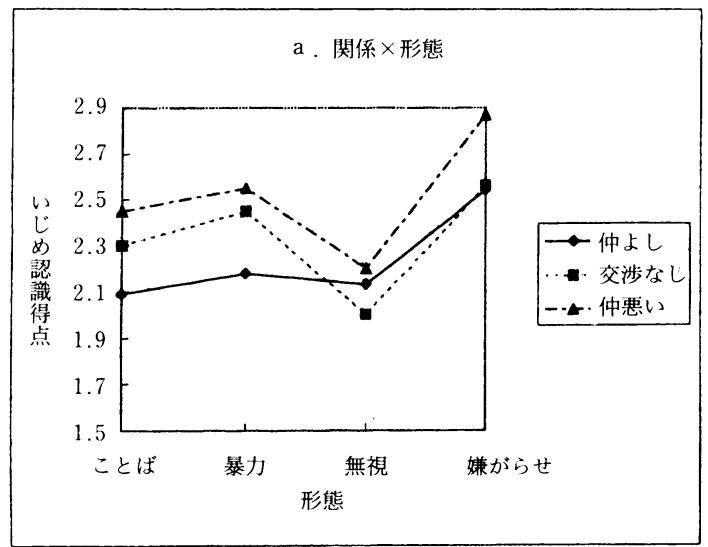

b. 背景 $\times$ 形態

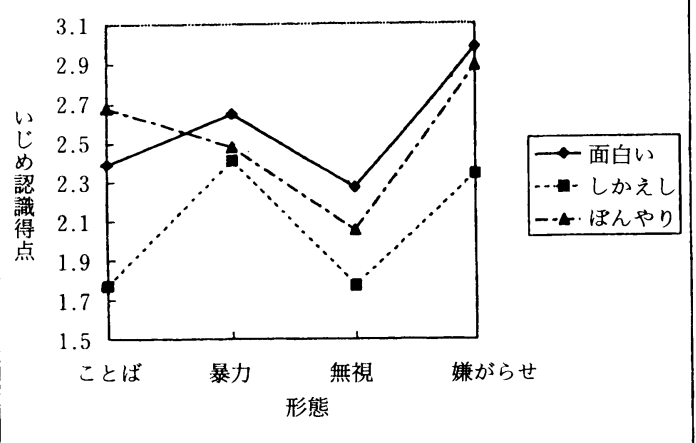

FIGURE 2 小学生の要因の組み合わせによる効果
(2.34))，ことばではほんやりの場合が最もいじめと認識 される(ぽんやり(2.68)>面白い(2.39)>しかえし(1.77))。ま た，しかえしという背景では，ことばと無視，暴力と 嫌がらせの間に，交渉なしでは暴力と嫌がらせの間に， 仲悪いでは,ことばと暴力の間に差がなかった。

以上のように, 関係, 背景, 形態という要因が, 小 学生のいじめ認識に影響を与えることが示された。こ れらの要因の影響から考えると一般的に「仲の悪い友 人が，面白がって嫌がらせをする」状況などがいじめ と認識されやすく, 逆に「仲良しの友人が, 自分の行 為のしかえしとして無視をする」状況などはいじめと 認識されにくいと推察される。しかしながら, “仲よし の友人からの無視はいじめと認識されやすい”，“㵋んん やりしているからという理由で，身体的欠点を言うこ とはいじめと認識されやすい”といった要因の組み合 わせによる影響も見られ，その行為が自分と相手との 関係によって許容されるものか, 行為の背景とその形 態(被害の程度)との相対関係などを考慮した相互作用的 な判断がなされていることが示唆された。

\section{3. 中学生のいじめ認識}

中学生の項目別, および各要因の水準別平均值と標 準偏差を TABLE 2 に示した。中学生に対しても，小学 生と同様に，標準誤差から算出した基準をもとに検討 していくこととする。要因別水準別に平均值を算出し たところ, 各平均値の標準誤差が $0.04 \sim 0.05$ であった。 よって, 要因の効果は平均値の差が1.5以上の場合に有 意な差があるものとみなす。

中学生においては，すべての要因の効果が見られた。 人数では「複数 $>$ 単数」, 関係では「仲悪い>交渉なし> 仲よし」, 背景では「面白い>ぽんやり>しかえし」, 形態では「嫌がらせ >無視 n.s.暴力 n.s.ことば」という 結果が得られた。関係, 背景の各要因においては, 小 学生とほほ同様の傾向が示された。しかし, 形態では, 小学生では最もいじめと認識されにくい形態であった 「無視」が, 他の形態と同程度にいじめと認識される ことが示された。

また, 人数 $\times$ 関係, 背景 $\times$ 関係, 関係 $\times$ 形態, 背景 $\times$ 形態においては, 要因の組み合わせによる効果が見ら れた。人数 $\times$ 関係 (基準: 0.18) では，仲の悪い友人の場 合だけ, 加害者の人数がいじめ認識に影響を及ぽすこ とが示された（仲よし：単数(1.97)n.s.複数(2.05)。以下同順で， 交渉なし : 2.25n.s.2.31, 仲悪い: $2.30>2.49)$ 。また, 加害者が 複数の場合, 仲の悪い友人の行為のほうが, 交涉のな い友人の行為より，いじめと認識される。

背景 $\times$ 関係 (基準: 0.15) では, 仲のよい友人の行為に 
TABLE 2 中学生の項目別要因別平均值

\begin{tabular}{|c|c|c|c|c|c|c|c|c|c|c|c|c|c|c|c|}
\hline & & \multicolumn{4}{|c|}{ (加害者が) 面白い } & \multicolumn{4}{|c|}{ (被害者の行為に対する)しかえし } & \multicolumn{4}{|c|}{ (被害者が)ほんやり } & \multirow{2}{*}{$\begin{array}{l}\text { 関係別 } \\
\text { 平均 }\end{array}$} & \multirow{2}{*}{$\begin{array}{l}\text { 人数別 } \\
\text { 平均 }\end{array}$} \\
\hline & & ことば & 暴力 & 無視 & 嫌がらせ & ことば & 暴力 & 無視 & 嫌がらせ & ことば & 暴力 & 無視 & 嫌がらせ & & \\
\hline \multirow{2}{*}{ 仲よし } & 単数 & $\begin{array}{c}1.72 \\
(.91)\end{array}$ & $\begin{array}{c}1.78 \\
(.93)\end{array}$ & $\begin{array}{c}2.66 \\
(1.03)\end{array}$ & $\begin{array}{c}2.40 \\
(1.07)\end{array}$ & $\begin{array}{c}1.57 \\
(.79)\end{array}$ & $\begin{array}{c}1.61 \\
(.78)\end{array}$ & $\begin{array}{l}1.84 \\
(.95)\end{array}$ & $\begin{array}{c}1.90 \\
(.92)\end{array}$ & $\begin{array}{c}2.08 \\
(1.04)\end{array}$ & $\begin{array}{c}1.98 \\
(.96)\end{array}$ & $\begin{array}{c}2.11 \\
(1.04)\end{array}$ & $\begin{array}{c}2.22 \\
(1.07)\end{array}$ & 仲よし & 単数 \\
\hline & 複数 & $\begin{array}{c}1.82 \\
(.94)\end{array}$ & $\begin{array}{c}1.97 \\
(1.01)\end{array}$ & $\frac{2.66}{(1.03)}$ & $\begin{array}{c}2.40 \\
(1.07)\end{array}$ & $\begin{array}{c}1.57 \\
(.79)\end{array}$ & $\begin{array}{l}1.74 \\
(.85)\end{array}$ & $\begin{array}{c}2.00 \\
(.98)\end{array}$ & $\begin{array}{c}2.03 \\
(.93)\end{array}$ & $\begin{array}{c}2.02 \\
(.94)\end{array}$ & $\begin{array}{c}1.98 \\
(.94)\end{array}$ & $\begin{array}{c}2.17 \\
(1.01)\end{array}$ & $\begin{array}{c}2.25 \\
(1.02)\end{array}$ & $\begin{array}{c}2.01 \\
(.71)\end{array}$ & $\begin{array}{c}2.16 \\
(.71)\end{array}$ \\
\hline \multirow{2}{*}{ 交涉なし } & 単数 & $\begin{array}{c}2.34 \\
(1.00)\end{array}$ & $\begin{array}{c}2.57 \\
(1.04)\end{array}$ & $\frac{2.23}{(1.14)}$ & $\begin{array}{c}2.83 \\
(1.03)\end{array}$ & $\begin{array}{c}1.78 \\
(.91)\end{array}$ & $\begin{array}{c}1.92 \\
(.91)\end{array}$ & $\begin{array}{c}1.78 \\
(.91)\end{array}$ & $\begin{array}{c}2.14 \\
(.98)\end{array}$ & $\begin{array}{c}2.42 \\
(1.01)\end{array}$ & $\begin{array}{c}2.36 \\
(1.00)\end{array}$ & $\begin{array}{c}2.10 \\
(1.07)\end{array}$ & $\begin{array}{c}2.59 \\
(1.06)\end{array}$ & 交渉なし & 複数 \\
\hline & 複数 & $\begin{array}{c}2.41 \\
(.94)\end{array}$ & $\begin{array}{c}2.62 \\
(1.01)\end{array}$ & $\frac{2.41}{(1.14)}$ & $\begin{array}{c}2.88 \\
(1.01)\end{array}$ & $\begin{array}{c}1.86 \\
(.91)\end{array}$ & $\begin{array}{c}1.98 \\
(.91)\end{array}$ & $\frac{1.89}{(.97)}$ & $\begin{array}{c}2.23 \\
(.97)\end{array}$ & $\begin{array}{c}2.43 \\
(1.09)\end{array}$ & $\begin{array}{c}2.34 \\
(1.02)\end{array}$ & $\begin{array}{c}2.08 \\
(1.09)\end{array}$ & $\begin{array}{c}2.62 \\
(1.05)\end{array}$ & $\begin{array}{c}2.25 \\
(.74)\end{array}$ & $\begin{array}{l}2.40 \\
(.74)\end{array}$ \\
\hline \multirow{2}{*}{ 仲悪い } & 単数 & $\begin{array}{c}2.41 \\
(1.03)\end{array}$ & $\begin{array}{c}2.69 \\
(1.03)\end{array}$ & $\begin{array}{c}2.41 \\
(1.14)\end{array}$ & $\begin{array}{c}2.92 \\
(1.00)\end{array}$ & $\begin{array}{c}1.84 \\
(.94)\end{array}$ & $\begin{array}{c}2.00 \\
(.92)\end{array}$ & $\begin{array}{c}1.85 \\
(.93)\end{array}$ & $\begin{array}{c}2.19 \\
(.94)\end{array}$ & $\begin{array}{c}2.38 \\
(1.06)\end{array}$ & $\begin{array}{c}2.31 \\
(1.00)\end{array}$ & $\begin{array}{c}2.09 \\
(1.03)\end{array}$ & $\begin{array}{c}2.59 \\
(1.05)\end{array}$ & 仲悪い & \\
\hline & 複数 & $\begin{array}{c}2.62 \\
(1.01)\end{array}$ & $\begin{array}{c}2.77 \\
(1.02)\end{array}$ & $\frac{2.74}{(1.14)}$ & $\begin{array}{c}2.99 \\
(1.02)\end{array}$ & $\begin{array}{c}2.06 \\
(1.04)\end{array}$ & $\begin{array}{c}2.18 \\
(.99)\end{array}$ & $\frac{2.15}{(1.04)}$ & $\begin{array}{c}2.37 \\
(1.03)\end{array}$ & $\begin{array}{c}2.49 \\
(1.09)\end{array}$ & $\begin{array}{c}2.45 \\
(1.08)\end{array}$ & $\frac{2.38}{(1.15)}$ & $\begin{array}{c}2.73 \\
(1.07)\end{array}$ & $\begin{array}{c}2.40 \\
(.76)\end{array}$ & \\
\hline & 面白 & & 一かえし & ほんや & & & こと & & 暴力 & 無視 & & がらせ & & & \\
\hline 背景別平均 & $\begin{array}{r}2.4 \\
(.7\end{array}$ & & $\begin{array}{c}1.92 \\
(.58)\end{array}$ & $\begin{array}{r}2.28 \\
(.74\end{array}$ & & 態別平均 & $\begin{array}{r}2.0 \\
\quad(.6\end{array}$ & & $\begin{array}{c}2.15 \\
(.67)\end{array}$ & $\frac{2.19}{(.72}$ & & $\begin{array}{l}2.43 \\
.76)\end{array}$ & & & \\
\hline
\end{tabular}

・ ( )内は標準偏差

•—_....は， $\mathrm{t}$ 検定による小中比較により，5\%水準で有意差が見られたもの（_は中＞小， ....は中<小）

対しては，面白いとぼんやりでは，いじめ認識に差が みられなかった（仲よし：面白い(2.16)n.s.ぽんやり (2.10)>し かえし(1.78)。以下同順で, 仲悪い：2.54>2.37>1.95, 交涉なし： $2.67>2.43>2.08)$ 。また, 面白いという背景では, 交涉な しの友人の行為のほうが, 仲悪い友人の行為よりいじ めと認識される。

関係×形態（基準 : 0.15）では（FIGURE 3-a），ことば， 暴力, 嫌がらせという形態においては，「仲悪いn.s.交 渉なし>仲良し」という順序でいじめと認識されるが (ことば : 仲悪い(2.30)n.s.交涉なし(2.21)>仲よし(1.79). 以下同 順で, 暴力 : 2.40n.s.2.28>1.84, 嫌がらせ : 2.63n.s.2.55>2.19), 無視の場合は, 仲よしと仲悪いとの間に差はなく, 交 渉なしの友人からされた場合が最もいじめと認識され にくい（仲悪い(2.27)n.s.仲よし(2.23)〉交渉なし(2.08))。また， 仲よしの友人からの行為の場合, 無視と嫌がらせの間 に差がなかった。

背景 $\times$ 形態（基準 : 0.15）では（FIGURE 3-b)，暴力， 無視, 嫌がらせという形態においては「面白い>ほん
やり>しかえし」という順でいじめと認識されていた が (暴力：面白い(2.39)>ほんやり(2.23)>しかえし(1.90)。以下 同順で, 無視 : $2.49>2.15>1.91$, 嫌がらせ : $2.70>2.49>2.14)$, ことばでは, ぼんやりと面白いという背景の間に差が なかった(济んやり(2.29)n.s.面白い(2.21)>しかえし(1.76))，ま た，面白いという背景でだけ，ことばと暴力に差があ り，しかえしでは，ことばと無視の間に差がなかった。 以上のように, 中学生においても 4 つの要因がいじ め認識に影響を及ほし，またそれらの要因を相互作用 的に考慮した判断がなされていることが示唆された。 中学生においては, 概して「仲の悪い複数の友人が, 面白がって嫌がらせをする」ような状況がいじめと認 識されやすく,「仲良しの 1 人の友人が, 自分のしたこ とのしかえしに悪口を言う」ような状況がいじめと認 識されにくいと言える。

\section{4. 小学生と中学生の対比}

以下に, 小学生と中学生のいじめ認識の発達的差異 について考察する。ここではいじめ認識の発達的差異 

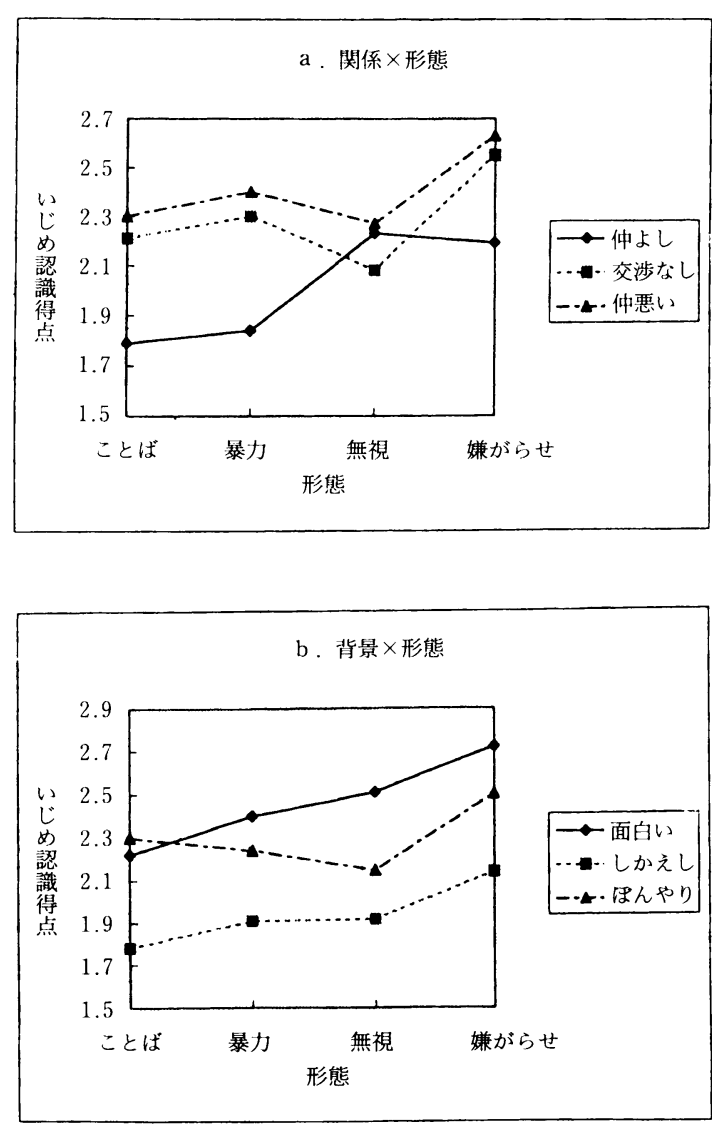

FIGURE 3 中学生の要因の組み合わせによる効果

をより明確に描き出すために，笠井ら(1996)が大学生・ 専門学校生に同様の様式を用いていじめ認識を調査し た結果に, 本研究と同様の処理を行ったものを引用し ながら考察する (TABLE 3 参照)。

項目別に小学生と中学生の結果を比較すると, 総じ て小学生のほうがいじめと認識しやすい傾向が示され た (TABLE 1, TABLE 2 参照)。しかし，大学生の結果と比 較すると, 大学生のほうが小学生よりも得点が高い。 中学生は小学生や大学生に比へ, 友人からの行為をい じめと認識する傾向が相対的に少ないと言えるだろう。 この結果から, 中学生は他者がいじめられている状況 を目撃しても, 軽くとらえて見過ごしてしまったり, 自分の行為もそれほど重大と思わないなどの危険性が 推測できる。

関係, 背景という要因がいじめ認識に及ほす影響は, よく似た傾向を示している。しかし，形態の効果は，
TABLE 3 大学生・専門学校生の「いじめ」認識得点 (笠井ら，1996を再処理したもの)

\begin{tabular}{|c|c|c|c|c|c|c|c|}
\hline \multirow[t]{2}{*}{ 関係 } & 仲よし & & 交涉なし & & 仲悪い & & \\
\hline & 2.20 & $<$ & 2.61 & n.s. & 2.68 & & \\
\hline \multirow[t]{2}{*}{ 人数 } & 单数 & & 複数 & & & & \\
\hline & 2.30 & $<$ & 2.69 & & & & \\
\hline \multirow[t]{2}{*}{ 背景 } & しかえし & & ほんやり & & 面白い & & \\
\hline & 2.10 & $<$ & 2.66 & n.s. & 2.72 & & \\
\hline \multirow[t]{2}{*}{ 形態 } & ことば & & 無視 & & 暴力 & & 嫌がらせ \\
\hline & 2.18 & $<$ & 2.37 & $<$ & 2.56 & $<$ & 2.89 \\
\hline
\end{tabular}

・<は $5 \%$ 水準で有意差があることを示す

それぞれの発達段階で異なっている。無視という形態 は, その相対的順位において, 中学生が最もいじめと 認識しやすい。また，小学生では人数の効果が見られ ない。このような発達的な差異がなぜ生じるのか, 今 後も検討していきたい点である。

\section{今後の課題}

（1）本研究の結果から，どのような行為(状況的要因の組 み合わせ）が児童・生徒に「いじめ」と認識されるか が，ある程度明らかになったといえるであろう。そし て，それらの多くは，我々の一般的ないじめ概念とほ ほ合致するものであった。また，多くの先行研究の結 果や事例研究などの考察と一致, あるいは補完し合う 点も多く, 本研究のような認知的なアプローチも「い じめ」現象をとらえる1つの方法となると考えられる。 特に,いじめている意識の欠如・希薄化が指摘されて いる今日，このようなアプローチも有効であると考え られる。

このようなアプローチの結果を具体的な参考資料と することにより，どのような行為がいじめと認識され るかという共通認識を形成したり，いじめの判断が個 人よって，また注目する状況要因によって異なること を理解し，相手の立場に立って考えることが可能とな るであろう。しかしそのためには、本研究で用いたよ うな状況を提示し，それがいじめか否かを児童・生徒 に判断させたり, 状況の違いに対応した感じ方の違い などについて討論させるような授業案作りといった, この結果をより効果的に利用する方策を模索していく ことが必要であろう。

（2）また, 本研究の結果は, 览童・生徒がいくつかの 要因の相互作用的な影響をうけながら，いじめの判断 をしていることを示唆している。これは竹村・高木 (1988) が，一元的な概念のみから「いじめ」の現象を 
とらえることができないと述べていることを裏付ける 結果である。児童・生徒が複数の要因から相互作用的 にいじめを認識していることを理解することは, 教員 がいじめへの指導や助言を行う際にも役立つものと思 われる。例えば「仲良しの友達に無視することは，た とえふざけているつもりでも，いじめととらえられや すい。もっと別の方法で表現するほうがよいのではな いか」といった個別の状況に即した，より具体的な指 導も可能になるであろう。

また,これらの結果は, 現実に生起した複雑ないじ め状況を相互作用的に理解する手がかりとなるであろ う。さらに，いじめへの指導・助言の際には, “状況の 個別性・独自性の理解”が不可欠であることを強調する ことにもつながる。指導的立場にある者には，その行 為の文脈や全体的状況などを考え合わせ，常にいじめ 状況の個別性や独自性を考慮した関わりをすることが 求められる。

（3） 今回の調査では, 友人の行為をどの程度いじめと 思うかと尋ねたが，同一場面に対する子どもたちの判 断には，大きな個人差があると予想される。例えば, 同一の行為を「ふざけている」ととらえる子どももい れば，「ケンカ」と考える子どももいるであろう。今後 のいじめに対する認知的アプローチの 1 つとして，子 どもたちがどのような基準 (要因)によってこれらの概 念 (例えば,いじめとふざけ) を識別しているかを明らかに していく必要がある。

（4）今回の調査では取りあげなかった「行為の継続性」 や「加害行為に対する被害者の反応」といった要因に ついても考えていく必要がある。また，新たな要因を 考えると同時に，それぞれの要因の相対関係 (影響力の 程度) や，性別や日常の友人関係，「いじめた」・「いじ められた」経験といった個人差の要因なども考慮して いく必要がある。本研究の結果から「○○という条件 下での行為がいじめと認識されやすい」というような, 客観的にいじめをとらえるための材料を提供すること はできる。しかし，個々の具体的ないじめに関わって いくためには，1 人ひとりの子どもの主観や個人差に まで踏み込んで理解していくことが不可欠であろう。 今後, 研究の中にそれらをどのように取り入れていく かが大きな課題である。

\section{引用文献}

江川玟成 1986 いじめから学ぶ 大日本図書

藤村 啓 1985 「いじめ」とその法的問題 ジュリス 卜 No.836, 44-48.
深谷和子 1995 「いじめ」の用語の再吟味 いじめ対

応と予防読本 坚童心理 臨時増刊, 643, 16-20. 深谷和子 1996 「いじめ」世界の子どもたち一教室の 深淵一 金子書房

深谷和子・中原美恵 1986 小学生の「いじめ」現代 のエスプリ No.228, 34-43.

古市裕一・余公俊晴・前田典子 1989 いじめにかか わる子どもたちの心理的特徵 岡山大学教育学部 研究集録, 81, 121-128.

濱口佳和・笠井孝久・川端郁恵・木村史代・中澤 潤・

三浦香苗 1996 「いじめ現象についての子ども たちの認識一架空のいじめエピソードに対する自 由記述のデータの分析一 千葉大学教育学部教育 相談研究センター年報, $13,25-44$.

稲村 博 1985 いじめの心理と病理 ジュリスト No.836, 23-28.

井上健治・戸田有一・中松雅寿 1986 いじめにおけ る役割 東京大学教育学部紀要, 26, 89-106.

笠井孝久 1996 「いじめ」の形態についての児童の認

識 千葉大学教育学部教育相談研究センター年 報, 13, 17-27.

笠井孝久 - 木村史代・永松未生・中澤 潤 - 三浦香苗 1996 小・中学生，大学生の“いじめ”認識 千葉 大学教育学部教育相談研究センター年報, 13,45 $-60$.

河井芳文 1985 「正義のいじめ」であることを知る 児童心理 10 月増刊号 Pp.48-49.

河井芳文 1986 囲いこまれた子ども達一現代の教育 と子どものいじめ一 田研出版株式会社

松本良夫 1985 座談会「いじめと現代社会」ジュリ スト No.836, 6-15.

森田洋司 1985 学級集団における「いじめ」の構造 ジュリストNo.836, 29-30.

森田洋司・清永賢二 1995 新訂版 いじめ一教室の 病い一 金子書房

オルウェーズ, D. 松井梖夫・角山 剛・都築幸恵 (訳) 1995 いじめこうすれば防げる川島書店 (Olweus,D. 1993 Bullying at school : What we know and what we can do. Oxford, Blackwell.)

坂本昇一 1995 現代の「いじめ」は異質なのか 教 育と医学 第 43 巻 11 号 慶応通信 Pp.4-10. シャープ, S., \& スミス,P.K. 奥田眞丈 (監訳) 1996 あなたの学校のいじめ解消にむけて 東洋館出版 社 (Sharp, S. \& Smith, P.K. 1994 Tackling 
bullying in your school. Routledge.)

鈴木康平 1995 いじめの実態・心理 教育と医学

第 43 巻 11 号 慶応通信 Pp.54-62.

高野清純 1986 いじめのメカニズム 教育出版

竹村和久・高木 修 1988 “いじめ”現象に関わる心

理的要因 教育心理学研究, 36, 57-62.

(1996.9.9 受稿, ’97.9.16 受理)

\section{APPENDIX I 提示条件}

以下のそれぞれの条件に、FIGURE 1 と同様の質問項目を尋ねた。 「仲よしメ単数」

いつもあなたといつしょに話したり遊んだりしている仲よ しのA君（さん）が，つぎの 1 ～12のようなことをしたら，あ なたはそれを「いじめ」だと思いますか。

「仲よしメ複数」

いつもあなたといつしょに話したり遊んだりしている，なん 人かの仲よしの同級生が，つぎの 1 ～12のようなことをした
らあなたはそれを「いじめ」だと思いますか。 「交涉なし×単数」

ふだん，あなたといっしょに遊んだりしないし，あまり話し もしない B 君（さん）が，つぎの 1 ～12のようなことをした ら，あなたはそれを「いじめ」だと思いますか。

「交涉なしメ複数」

ふだん，あなたといっしょに遊んだりしないし，あまり話し もしないなん人かの同級生が, つぎの 1 ～12のようなことをし たら，あなたはそれを「いじめ」だと思いますか。

「仲悪い $\times$ 単数」

よくあなたにいじわるをしてきて，あなたとケンカしたりし ている仲の悪い C君（さん）が，次の 1 12のようなことをし たら，あなたはそれを「いじめ」だと思いますか。 「仲悪いメ複数」

よくあなたにいじわるをしてきて，あなたとケンカしたりし ている仲の悪いなん人かの同級生が, 次の 1 12のようなこと をしたら，あなたはそれを「いじめ」だと思いますか。 